Published online on the journal's webpage: https://jbe-upiyptk.org/ojs/index.php/jbe

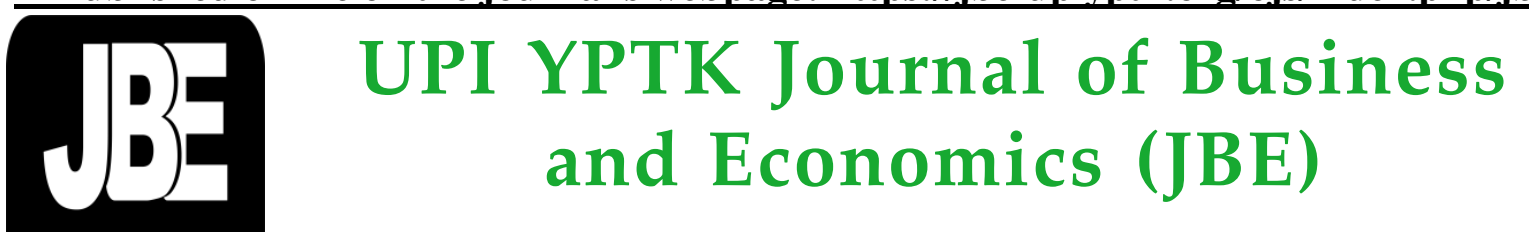

UPI YPTK JBE

Vol. 6 No. 3 September (2021)

ISSN Electronic Media: 2527-3949

\title{
The Influence of Corporate Governance and Investment Opportunity Set on Firm Value: CSR as Moderating Variable
}

\author{
Weni Apriliana ${ }^{1}$, Yosi Yulia ${ }^{2}$, Sigit Sanjaya ${ }^{3 *}$ \\ 1,2,3 Department of Accounting, Faculty of Economics and Business, Universitas Putra Indondeia YPTK Padang \\ *sigitsanjaya@upiyptk.ac.id
}

\begin{abstract}
The object of this study is a manufacturing company listed on the Indonesia Stock Exchange for the period 2016-2020 with a total population of 196 companies. The sample of this research is 44 companies that meet the criteria based on purposive sampling. The analysis technique uses multiple linear regression.The results of this study there is a significant relationship between the independent board of commissioners on firm value. Institutional ownership has no effect on firm value. There is a significant relationship between the audit committee and the investment opportunity set on firm value. The results of other studies indicate that there is an influence of the CSR moderating variable between the independent board of commissioners' relationship to firm value. It is different with institutional ownership that has no effect on the value of the company which is moderated by CSR. There is a significant effect between the audit committee and the investment opportunity set on firm value moderated by CSR in manufacturing companies listed on the Indonesia Stock Exchange for the 2016-2020 period.
\end{abstract}

Keywords: CSR, independent board of commissioners, investment opportunity set, institutional ownership, audit committee, firm value.

\section{Introduction}

was a very sharp decline in performance. This is The Indonesian economy is still moving forward in line suspected to be due to the Covid-19 pandemic that has with the movement of the world economy. This spread throughout the world. This pandemic has not economic movement is supported by the activities of only affected health but also the economy, including companies ranging from micro, small, medium, and the capital market in Indonesia. Throughout 2020 to large. Large companies that already have sufficient January 2021, the company's performance bounced capital and good growth will list their companies on the back even though it was still in an unstable and difficult capital market. In Indonesia itself, the Indonesia Stock to predict condition.

Exchange (IDX) has until now been a market for companies and investors.

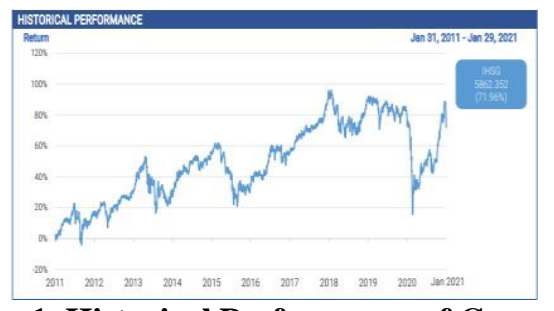

Figure 1. Historical Performance of Companies

Listed on the Indonesia Stock Exchange (IDX)

The company is a group of people who work to achieve a goal in an organization. The long-term goal that is a priority for a company is to increase the value of the company because by increasing the value of the company it can prosper the shareholders. Corporate Governance (CG) is one of the factors that can affect the value of the company. Corporate governance is said to be able to increase the value of the company due to the existence of corporate governance, the company is expected to have good performance so as to create profits for company owners or shareholders.(Widodo, 2019).

The purpose of every company, both public

Based on Figure 1 above, you can see a graph and non-going companies, is to increase the value of of the historical performance of all companies listed on the company (Yuningsih \& Novitasari, 2020). The the Indonesia Stock Exchange (IDX) from January value of the company can be influenced by various 2011 to January 2021. Historical performance is factors, both internal and external to the company. So measured based on stock returns of companies listed on the company should maintain that these factors can be the IDX. It can be seen that the movement of the graph maximized so that they can achieve company goals fluctuated with an increasing trend from 2011 to the such as increasing company value.

end of 2020. However, at the beginning of 2020 there

Accepted by editor: July 20, 2021 | Final Revision: August 10, 2021 | Online Publication: Sept 01, 2021 
Corporate Governance (CG) is one of the keys to a company's success to grow and be profitable CSR (Corporate Social Responsibility) is a business in the long term, as well as win global business commitment to act ethically, operate legally and competition. The current challenges of corporate contribute to economic improvement along with governance practices have not been fully implemented improving the quality of life of employees and their by entrepreneurs. determine the direction of the families, the local community and society at large. company's performance. The implementation of Corporate social responsibility is an obligation that corporate governance is very necessary to fulfill the must be carried out by the company, no longer a trust of the public and the international community as voluntary activity. Companies that carry out corporate an absolute requirement for companies to develop social responsibility activities certainly have their own properly and healthily whose ultimate goal is to realize competitive advantages. Corporate social responsibility shareholder value.(Purnamawati et al., 2017).

now needs to be disclosed in the company's financial

The board of commissioners consists of statements. This disclosure can have an impact on a several commissioners, one of which is an independent positive company image in the eyes of the public and commissioner. The term independent on independent investors. A positive outlook will increasingly attract commissioners indicates their existence as the attention of investors which has an impact on representatives of independent (minority) shareholders increasing the value of the company. However, and also represents the interests of investors(Surya \& sometimes there are investors who do not believe in Yustiavandana, 2008). Independent commissioners corporate social responsibility activities(Princess \& have the understanding that they are expected to be able Mardenia, 2019).

to carry out their duties independently, in order to Al-Gamrh et al. (2020)conduct research on achieve the company's interests and regardless of the investment opportunities, corporate governance quality, influence of various parties who have certain interests. and company performance. The corporate governance These interests can also conflict with the interests of the quality variable is measured using an index, investment company and must be avoided. Thus, independent opportunity is measured using market to book value, commissioners act in a neutral manner and encourage and company performance is measured using return on the implementation of (CG) corporate governance assets. The results of the study show that investment principles.

Jensen \& Meckling (1976) states that performance. Meanwhile, corporate governance quality institutional ownership has a very important role in has a positive effect on moderating the relationship minimizing agency conflicts that occur between agents between investment opportunities and company and principals. Institutional ownership acts as a performance.

controlling party for company managers. It can be Zhang et al. (2020) conducted a study on argued that the presence of institutional investors is corporate governance, social responsibility disclosure, expected to be an effective monitoring mechanism for and banking performance. Banking performance every decision-making by management so that the variables were measured using ROA and ROE. presence of institutional owners will encourage more Meanwhile, corporate governance and social optimal supervision.

responsibility disclosure are measured using an index.

Agency theory predicts that the formation of The results showed that there was no influence between an audit committee is a way to resolve agency conflicts. corporate governance and CSR on banking Surya \& Yustiavandana (2008) explained that the audit performance.

committee is an additional part needed in the Study conducted by Kabir \& Thai (2017)is implementation of corporate governance (CG) about the relationship of CSR to financial performance principles. The Audit Committee is required to act by moderating corporate governance. Financial independently in carrying out its duties and performance variables were measured using ROE, responsibilities.

ROA, return on sales (ROS), Tobin's $\mathrm{Q}$, and stock

Investment Opportunity Set(IOS) is a return (RET). CSR variable is measured using an index combination of assets in place and investment options based on the global reporting initiative (GRI) and in the future with a positive net present value. corporate governance is measured by state ownership Investment policy concerns the decision on the and independent directors. The results show that CSR allocation of funds originating from outside the has a positive effect on financial performance. company in various forms of investment. Financial Meanwhile, independent directors have an influence on management decides on the use of funds obtained by the relationship between CSR and financial the company, either from banks or from the capital performance.

market or from other parties, to be invested in fixed Based on the literature and previous research, assets and current assets. Investment is an act of issuing the framework of the research to be carried out can be funds now which is expected to obtain cash inflows at described in figure 2 below.

times to come, during the life of the project(Judge,

2019). 


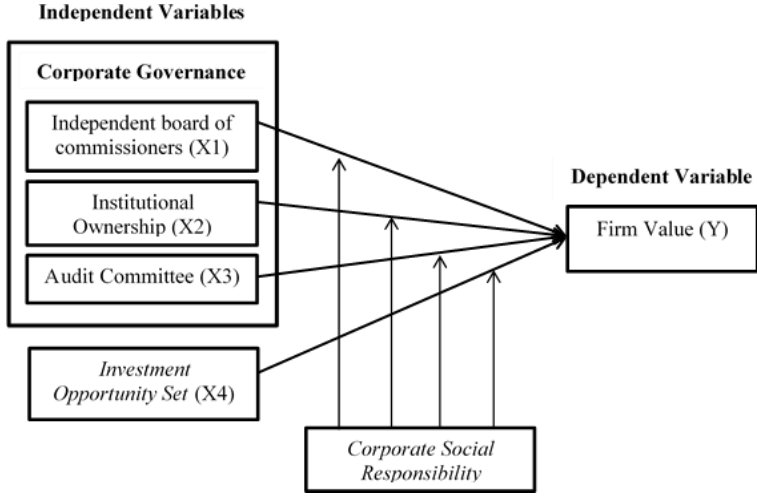

Figure 2. Research Framework

Based on the framework presented, the following hypotheses can be developed.

$\mathrm{H}_{1}$ : Independent commissioners have a positive and effect on the firm value of manufacturing companies listed on the Indonesia Stock Exchange for the period 2016 - 2020 .

$\mathrm{H}_{2}$ : Institutional ownership has a positive and significant effect on the firm value of manufacturing companies listed on the Indonesia Stock Exchange for the period 2016 2020.

$\mathrm{H}_{3}$ : Audit committee has a positive and significant effect on the firm value of manufacturing companies listed on the Indonesia Stock Exchange for the period 2016-2020.

$\mathrm{H}_{4}$ : Investment Opportunity Set has a positive and significant effect on the firm value of institutional ownership $\left(\mathrm{X}_{2}\right)$, audit committee $\left(\mathrm{X}_{3}\right)$, and manufacturing companies listed on the Investment opportunity set $\left(\mathrm{X}_{4}\right)$ with moderation Indonesia Stock Exchange for the period 2016 - namely Corporate Social Responsibility (CSR). 2020.

$\mathrm{H}_{5}$ : Corporate Social Responsibility moderates measurement of firm value (Y) using the Tobin's Q independent commisionaire and firm value of ratio as follows.

manufacturing companies listed on the Indonesia Stock Exchange for the period 2016 2020.

$\mathrm{H}_{6}$ : Corporate Social Responsibility moderates institutional ownership and firm value of manufacturing companies listed on the Indonesia Stock Exchange for the period 2016 2020.

$\mathrm{H}_{7}$ : Corporate social responsibility moderates audit committee and firm value of manufacturing companies listed on the Indonesia Stock Exchange for the period 2016-2020.

H8: Corporate Social Responsibility moderates Investment Opportunity Set and firm value of manufacturing companies listed on the Indonesia Stock Exchange for the period 2016 2020 .

\section{Method}

The population in this study are manufacturing companies that went public on the Indonesia Stock Exchange during the 2016-2020 period, totaling 196 Vira \& Wirakusuma (2019) explains the
measurement of firm value (Y) using the Tobin's Q

companies. Determination of the sample used by purposive sampling method with a Judgment Sampling approach, namely the sample selected based on the researcher's assessment that the manufacturing company is the most suitable company. (Sugiyono, 2014). Based on the selected sample criteria are presented in the following table.

Table 1. Sample Selection Criteria

\begin{tabular}{clc}
\hline No & \multicolumn{1}{c}{ Information } & Total \\
\hline 1. & $\begin{array}{l}\text { Manufacturing Companies listed on } \\
\text { the Indonesia Stock Exchange for } \\
\text { the 2016-2020 period. }\end{array}$ & 196 \\
2. & $\begin{array}{l}\text { Manufacturing companies that do } \\
\text { not publish a complete annual report } \\
\text { or annual report for the 2016-2020 } \\
\text { period. }\end{array}$ \\
3. & \\
$\begin{array}{l}\text { The company does not use rupiah } \\
\text { currency in its financial statements. }\end{array}$ & (12) \\
Manufacturing companies that do \\
not publish data on the structure of \\
share ownership, commissioners, \\
and corporate social responsibility. \\
Total of Companies \\
Total (for 5 vears)
\end{tabular}

The dependent variable is firm value (Y), while the independent variable consists of Corporate governance with independent commissioners $\left(\mathrm{X}_{1}\right)$, .

\section{.}

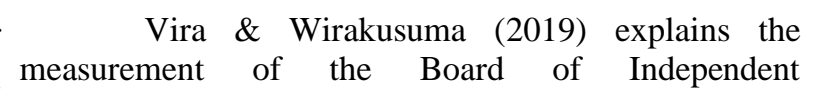
Commissioners $\left(\mathrm{X}_{1}\right)$ as follows.

\section{$I C=\frac{\text { Number of Independent Board of Commisioners }}{\text { Total Board of Commisioners }}$}

Vira \& Wirakusuma (2019) explaining the measurement of Institutional Ownership $\left(\mathrm{X}_{2}\right)$ for a company is as follows.

$$
\text { INS_OWN }=\frac{\text { Number of Institutional Ownership }}{\text { Total Outstanding Shares }}
$$

Vira \& Wirakusuma (2019) explains the measurement of the Audit Committee $\left(\mathrm{X}_{3}\right)$ by calculating the percentage of the comparison of the 
number of audit committees with the total number of boards of commissioners in the company.

$$
\text { AUD_COM }=\frac{\text { Number of Audit Committee Member }}{\text { Total Board of Commisioners }}
$$

Wulanningsih \& Agustin (2020)describes the measurement of IOS $\left(\mathrm{X}_{4}\right)$ with Market to Book Value Equity (MBVE).

$$
M B V E=\frac{\text { Total Outstanding Shares } \times \text { Closing Price }}{\text { Total Equity }}
$$

Vira \& Wirakusuma (2019)explained that the CSR disclosure policy $(\mathrm{Z})$ was measured in the number of CSR disclosures using the Corporate Social Responsibility Index (CSRDI) proxy based on the Global Reporting Initiative Generation 4 (GRI G4) with options according to the core, namely 91 indicators of special standard disclosures.

$$
\operatorname{CSRDI}=\frac{\sum X i}{n} \times 100 \%
$$

The data analysis used is multiple linear regression which can be explained in the following equation.

Yit $=+\beta_{1}$ X1it $+\beta_{2}$ X2it $+\beta_{3}$ X3it $+\beta_{4} X 4$ it $+\beta_{5}$ $(X 1$ it $*$ Zit $)+\beta_{6}(X 2$ it $*$ Zit $)+\beta_{7}(X 3$ it $*$ Zit $)+\beta_{8}$ $(\mathrm{X} 4 \mathrm{it} * \mathrm{Zit})+\varepsilon$

$$
\begin{aligned}
& \text { Company Value: Firm Value (Tobin's Q) } \\
& \begin{array}{ll}
\text { : constant } \\
\beta \quad \text { :regression coefficient for each independent } \\
\text { variable }
\end{array} \\
& \text { X1it } \quad \text { independent board of commissioners } \\
& \mathrm{X} 2 \mathrm{it} \quad \text { : institutional ownership } \\
& \mathrm{X} 3_{\text {it }} \quad \text { : audit committee } \\
& \mathrm{X} 4_{\text {it }} \quad \text { : investment opportunity set } \\
& \mathrm{Zit} \quad \text { : corporate social responsibility } \\
& \varepsilon \quad \text { : error }
\end{aligned}
$$

\section{Results and Discussion \\ Results}

Descriptive statistical analysis is intended to describe the data that can be seen from the average value (mean), median value, maximum value, minimum value, and standard deviation of the research variables. In summary, descriptive statistics are presented in the following table.
Table 2. Descriptive Statistics

\begin{tabular}{lcccccc}
\hline & DKL & KL & KA & IOS & CSR & TOBIN'S O \\
\cline { 2 - 3 } mean & 0.427 & 0.814 & 0.798 & 4.756 & 0.188 & 2.139 \\
median & 0.400 & 0.903 & 0.750 & 1.505 & 0.181 & 0.871 \\
Maximum & 1,000 & 0.999 & 1,500 & 82.44 & 0.450 & 21.95 \\
Minimum & 0.000 & 0.000 & 0.307 & 0.250 & 0.054 & -0.105 \\
Std. Dev. & 0.159 & 0.252 & 0.300 & 11.06 & 0.071 & 3,491 \\
\hline
\end{tabular}

Processed by researchers (2021)

Tobin's Q (Y) as the dependent variable has the lowest value of -0.101755 and the highest value is recorded at 21.95665. While the average is 2.139484 and the standard deviation is 3.491229. The Independent Board of Commissioners (X1) has the lowest score of 0 and the highest value is recorded at 1 with an average variable of 0.427251 and a standard deviation of 0.159769 . Institutional Ownership (X2) has the lowest value of 0.000278 and the highest value of 0.999867 with an average variable of 0.814733 and a standard deviation of 0.252295. The Audit Committee (X3) has the lowest score of 0.307692 and the highest score of 1.500000 with an average variable of 0.798514 and a standard deviation of 0.300051 . The Investment Opportunity Set (X4) has the lowest value of 0.250017 and the highest value of 82.44443 with a variable average of 4.756548 and a standard deviation of 11 ,

The selection of panel data regression estimates is carried out using the Chow test first. The following are the results of the Chow Test that has been carried out.

Table 3. Chow Test Results

\begin{tabular}{lrrr} 
Effects Test & Statistics & df & Prob. \\
\hline & & & \\
Cross-section F & 25.124577 & $(43,168)$ & 0.0000 \\
Cross-section Chi-square & 441.236279 & 43 & 0.0000 \\
\hline
\end{tabular}

Processed by researchers (2021)

Based on the results of the Chow test using Eviews 10, the Chi-square probability is 0.0000 . The resulting probability value is smaller than the significant level $(\alpha=0.05)$, so it can be concluded that the better estimate used in this model is the fixed effect model compared to the common effect. Based on the selected model, namely the fixed effect model, the test continued with the Hausman test.

\begin{tabular}{llll}
\hline \multicolumn{4}{c}{ Table 4. Hausman Test Results } \\
\begin{tabular}{llll}
\hline Test Summary & $\begin{array}{l}\text { Chi-Sq. } \\
\text { Statistics }\end{array}$ & Chi-Sq. df & Prob. \\
\hline Cross-section random & 34.504101 & 8 & 0.0000 \\
\hline Processed by researchers $(2021)$
\end{tabular}
\end{tabular}

Processed by researchers (2021)

Based on the results of the Hausman test using Eviews, the probability is 0.0000 . The probability value 
is smaller than the significant level $(\alpha=0.05)$, then a good model to use is a fixed effect compared to a the probability value of Prob. Chi-Square is 0.3733 random effect. Furthermore, before estimating the which is greater than (0.05). This test means that there panel data regression with the selected model, the is no heteroscedasticity problem in this data. classical assumption test is first performed. The Furthermore, panel data regression estimation is carried classical assumption test performed is the normality test, out with moderating variables using the Fixed Effect multicollinearity test, and heteroscedasticity test. The model which is presented in the following table. following are the results of the normality test carried out.

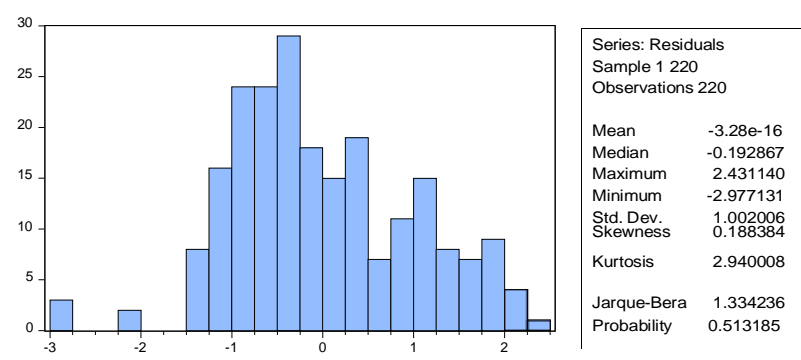

Figure 3. Normality Test Results

Based on Figure 3 above can be seen that the residual data is normally distributed where the JarqueBera value is 1.334236 and the probability is 0.513185 or greater ( $>$ ) than the probability level of 0.05 so that it is considered feasible to perform panel regression test.
Furthermore, the multicollinearity test is carried out which is presented in the following table.

Table 5. Multicollinearity Test Results

\begin{tabular}{|c|c|c|}
\hline Variable & $\begin{array}{l}\text { Centered } \\
\text { VIF }\end{array}$ & Information \\
\hline DKI & 1.005278 & $\begin{array}{c}\text { There are no symptoms of } \\
\text { multicollinearity }\end{array}$ \\
\hline $\mathrm{KI}$ & 1.231545 & $\begin{array}{c}\text { There are no symptoms of } \\
\text { multicollinearity }\end{array}$ \\
\hline KA & 7.568393 & $\begin{array}{c}\text { There are no symptoms of } \\
\text { multicollinearity }\end{array}$ \\
\hline IOS & 7.371067 & $\begin{array}{c}\text { There are no symptoms of } \\
\text { multicollinearity }\end{array}$ \\
\hline CSR & 1.123294 & $\begin{array}{c}\text { There are no symptoms of } \\
\text { multicollinearity }\end{array}$ \\
\hline
\end{tabular}

Processed by researchers (2021) variable, namely Company Value moderated by CSR is (he remaining $5.32 \%$ is determined by independent and moderating variables have a value of other variables not analyzed in the model in this study. Centered VIF $<10$. So it can be concluded that this

research data is free from multicollinearity. Discussion

Furthermore, the heteroscedasticity test is carried out which is presented in the following table.
$\mathrm{KA} * \mathrm{CSR}$
$-21,42819$
5.588582
$-3.8342800 .0002$
$\mathrm{IOS} * \mathrm{CSR}$
$-1.778607$
0.188123
$\begin{array}{lll}-9.454471 & 0.0000\end{array}$

Table 6. Heteroscedasticity Test Results

Heteroskedasticity Test: Breusch-Pagan-Godfrey

F-statistics

1.069194Prob. F(5,214)

Obs*R-squared

5.361912Prob. Chi-Square(5)

Scaled explained SS 4.921250Prob. Chi-Square(5)

Processed by researchers (2021)
Table 7. Estimated Results of Fixed Effect Moderation Panel Data Regression

\begin{tabular}{crrrr}
\hline Variable & Coefficient & Std. Error & t-Statistic & Prob. \\
\hline C & 1.329601 & 0.829058 & 1.603751 & 0.1106 \\
DKI & -5.732580 & 2.434282 & -2.354937 & 0.0197 \\
KI & 0.241431 & 1.002918 & 0.240728 & 0.8101 \\
KA & 2.650799 & 1.219199 & 2.174214 & 0.0311 \\
IOS & 0.737925 & 0.060805 & 12.13593 & 0.0000 \\
DKI*CSR & 34.71427 & 10.50348 & 3.305028 & 0.0012 \\
KI*CSR $^{*}$ CSR & -0.273652 & 5.704840 & -0.047968 & 0.9618
\end{tabular}

Cross-section fixed (dummy variables)

R-squared $\quad 0.959153$

Adjusted R-squared $\quad 0.946753$

0.000000

Processed by researchers (2021)

Based on table 7 above, it was obtained Simultaneous Test with the moderating panel regression equation that the prob value was $0.0000<$ 0.05 and indicated the F statisric 77,35113 therefore it can be concluded that the variables of the Independent Board of Commissioners $\left(\mathrm{X}_{1}\right)$, Institutional Ownership $\left(\mathrm{X}_{2}\right)$, Audit Committee $\left(\mathrm{X}_{3}\right)$, and Investment Opportunity Set $\left(\mathrm{X}_{4}\right)$ simultaneously have a positive and significant effect on Company Value moderated by CSR. While the value of Adjusted R-squared for the regression equation with the moderating variable obtained is 0.946753 or $94.68 \%$. These results indicate that the contribution of the independent variables, namely the Independent Board of Commissioners $\left(\mathrm{X}_{1}\right)$, Institutional Ownership $\left(\mathrm{X}_{2}\right)$, Audit Committee $\left(\mathrm{X}_{3}\right)$, and Investment Opportunity Set $\left(\mathrm{X}_{4}\right)$ to the dependent

Based on the results of the statistical $t$ test of the Independent Board of Commissioners variable is 2. 354937 with a prob level of $0.0197<0.05$, it means
that partially there is an influence between the $0.3784 \mathrm{In}_{\text {dependent Board of Commissioners on Company }}$ $\underline{0.4256}$ vese results indicate that the increase in the Independent Board of Commissioners is able to maximize the value of the company.
77.35113 
Weni Apriliana, Yosi Yulia, Sigit Sanjaya

UPI YPTK Journal of Business and Economics (JBE) Vol. 6 No. 3 September (2021)

DOI: https://doi.org/10.35134/jbe.v6i3.30

Creative Commons Attribution 4.0 International License (CC BY 4.0) 
Research conducted by Al Farooque et al. variable with CSR is 3.305028 with a prob level of (2020) explain the power of the board of directors of $0.0012<0.05$ meaning that partially there is an companies in Thailand as well as managerial ownership influence between the Independent Board of in determining the financial performance of companies Commissioners on Company Value with CSR as and reducing agency costs. The results of this study are moderating. So it can be concluded that H5 is accepted. in line with researchAl Farooque et al. (2020), Puni \& These results indicate that the influence between the Anlesinya (2020), and Kabir \& Thai (2017)who found Independent Board of Commissioners and CSR as a that the independence of the board of directors had a moderator is able to maximize Company Value. The positive and significant effect. But different from existence of an Independent Board of Commissioners researchWidodo (2019)who found that independent in the company is able to maximize the value of the commissioners had no effect on firm value (Tobin's Q) company. Companies that carry out good corporate

Based on test results, $t$ statistic of the governance or $(\mathrm{CG})$ corporate governance will obey the Institutional Ownership variable is 0.240728 with a rules so that the implementation of CSR is also carried prob level of $0.8101>0.05$, which means that partially out properly. These results are in line with there is no influence between Institutional Ownership researchArianti \& Putra (2018) who found that CSR on Firm Value. So it can be concluded that $\mathrm{H} 2$ is had an effect on firm value.

rejected. These results indicate that the increase in Based on the table,it is known that the $t$ institutional ownership has not been able to maximize statistic of the variable Institutional Ownership with firm value.Judge (2019)explained that as one of the CSR is -0.047968 with a prob level of $0.9618>0.05$ tools of the Corporate Governance mechanism, the meaning that partially there is no influence between presence of an institution that oversees the majority of Institutional Ownership on Company Value with CSR shares will be an effective monitoring tool to monitor as moderating. So it can be concluded that H6 is management performance so as to reduce agency costs. rejected. These results indicate that the effect of The results of this study are in line with institutional ownership with CSR as a moderator has researchYuningsih \& Novitasari (2020), Widodo not been able to maximize firm value.Zhang et al. (2019), and Arianti \& Putra (2018)who found that (2020)explained that measurement problems for institutional ownership had no effect on firm value. corporate governance and CSR variables can cause

Based on test resultsThe $t$ statistic of the Audit unobservable relationships. So this result is in Committee variable is 2.174214 with a prob level of accordance with the researchZhang et al. (2020), $0.0311<0.05$, meaning that there is partially an Purnamawati et al. (2017) and Widodo (2019)who influence between the Audit Committee on Firm Value. found the result that there was no influence of CSR So it can be concluded that $\mathrm{H} 3$ is accepted. These between the relationship of corporate governance to results indicate that the increase in the Audit firm value. So it can be concluded that institutional Committee is able to maximize the value of the ownership cannot maximize firm value.

company.Surya \& Yustiavandana (2008)explained that

Based on the table, it is known that the $t$ the audit committee is an additional part that is needed statistic of the Audit Committee with CSR variable is in the (CG) principles of corporate governance. The 3.834280 with a prob level of $0.0002<0.05$, meaning results of this study indicate that the existence of the that partially there is an influence between the Audit audit committee is well executed and fulfills its Committee on Company Value with CSR as responsibilities so as to maximize firm value. The moderating. So it can be concluded that $\mathrm{H} 7$ is accepted. results of this study are contrary to researchAl These results indicate that the influence between the Farooque et al. (2020), Puni \& Anlesinya (2020), Audit Committee and CSR as a moderator is able to Widodo (2019), and Arianti \& Putra (2018).

maximize Company Value.Wati et al. (2019)explained

Based on test resultsThe $t$ statistic of the that CSR disclosure in the company's annual report will Investment Opportunity Set variable is 12.13593 with a improve and strengthen the company's image, prob level of $0.0000<0.05$, meaning that partially there especially towards investors and potential investors and is an influence between the Investment Opportunity Set the public in general. The better the company's image, on the Firm Value. So it can be concluded that H4 is the more harmonious and sustainable relationships with accepted. These results indicate that the increase in IOS stakeholders will be. Based on this explanation and in is able to maximize Firm Value. Companies that have a line with this research, the influence of CSR can high level of Investment Opportunity Set (IOS) due to strengthen the relationship of corporate governance to investment will tend to have increased company growth firm value. So it can be stated that the audit committee prospects in the future.(Wulanningsih \& Agustin, 2020). can maximize the value of the company with good CSR. The results of this study are in line with Wulanningsih Based on the table,It is known that the $\mathrm{t}$ \& Agustin (2020), Al-Gamrh et al. (2020), and statistic of the Investment Opportunity Set variable Yuningsih \& Novitasari (2020)who found that IOS had with CSR is -9.454471 with a prob level of $0.0000<$ an effect on Firm Value.

0.05 meaning that partially there is an influence

Based on the table, it is known that the $\mathrm{t}$ between the Investment Opportunity Set on Company statistic of the Independent Board of Commissioners Value with CSR as moderating. So it can be concluded 
that $\mathrm{H} 8$ is accepted. These results indicate that the effect of the Investment Opportunity Set with CSR as a moderator is able to maximize firm value. Al-Gamrh et al. (2020) explained that the higher the level of investment opportunities will require higher resources. This can lead to failure and have a negative impact on the value of the company. Based on this explanation and in line with this research, CSR can have an effect on the relationship between investment opportunity set and firm value. Investment opportunity set will be able to affect the value of the company.

\section{Conclusion}

The results of this study indicate that there is a significant relationship between the independent board of commissioners and firm value. Institutional ownership has no effect on firm value. There is a significant relationship between the audit committee and the investment opportunity set on firm value. The results of other studies indicate that there is an influence of the CSR moderating variable between the independent board of commissioners' relationship to firm value. It is different with institutional ownership that has no effect on the value of the company which is moderated by CSR. There is a significant effect between the audit committee and the investment opportunity set on firm value moderated by CSR in manufacturing companies listed on the Indonesia Stock Exchange for the 2016-2020 period.

In further research, it is recommended to increase the observation period and the variation of research variables that affect firm value. This research has implications on the overall value of manufacturing companies listed on the IDX.

\section{References}

Al-Gamrh, B., Ku Ismail, KNI, Ahsan, T., \& Alquhaif, A. (2020). Investment opportunities, corporate governance quality, and firm performance in the UAE. Journal of Accounting in Emerging Economies, 10(2), 261-276. https://doi.org/10.1108/JAEE-12-2018-0134

Al Farooque, O., Buachoom, W., \& Sun, L. (2020). Board, audit committee, ownership and financial performance - emerging trends from Thailand. Pacific Accounting Review, 32(1), 54-81. https://doi.org/10.1108/PAR-10-2018-0079

Arianti, NPA, \& Putra, PMJS (2018). The Effect of Profitability on the Relationship of Corporate Social Responsibility \& Good Corporate Governance on Company Value. Scientific Journal of Management \& Accounting, 24(1) 20-46.

Hakim, L. (2019). Effect of Return on Assets, Investment Opportunity Set and Good Corporate Governance on LQ45 Firm Value.
IQTISHADUNA: Economics $\quad$..., 8(1), 33-42. http://ejournal.stiesyariahbengkalis.ac.id/index.ph p/iqtishaduna/article/view/150

Jensen, MC, \& Meckling, WH (1976). Theory of the firm: Managerial behavior, agency costs and ownership structure. Journal of Financial Economics. https://doi.org/10.1016/0304405X(76)90026-X

Kabir, R., \& Thai, HM (2017). Does corporate governance shape the relationship between corporate social responsibility and financial performance? Pacific Accounting Review, 29(2), 227-258. https://doi.org/10.1108/par-10-20160091

Puni, A., \& Anlesinya, A. (2020). Corporate governance mechanisms and firm performance in a developing country. International Journal of Law and Management, 62(2), 147-169. https://doi.org/10.1108/IJLMA-03-2019-0076

Purnamawati, IGA, Yuniarta, GA, \& Astria, PR (2017). Good Corporate Governance And Its Influence On Company Value Through Corporate Social Responsibility Disclosure. Journal of Finance and Banking, 21(2), 276-286. https://doi.org/10.26905/jkdp.v21i2.505

Putri, KAT, \& Mardenia, L. (2019). The Influence of GCg, CSR, Profitability And Company Size on Company Value. Scientific Journal of the Wahana Accounting, 14(2), 156-169. https://doi.org/doi.org/10.21009/wahana.14.024

Sugiyono. (2014). Data collection technique. In Quantitative, Qualitative and R\&D Research Methods. https://doi.org/10.3354/dao02420

Surya, I., \& Yustiavandana, I. (2008). Implementation of Good Corporate Governance: Overriding Privileges for Business Continuity (First). Kencana Prenada Media Group.

Vira, AN, \& Wirakusuma, MG (2019). The Effect of Corporate Social Responsibility Disclosure on Company Value With Good Corporate Governance as Moderating. E-Journal of Accounting, 26, 1299. https://doi.org/10.24843/eja.2019.v26.i02.p17

Wati, LN, Syahdam, GR, \& Prambudi, B. (2019). The Role of Disclosure of CSR and GCG Mechanisms on Financial Performance on Company Value. Journal of Ecodemica: Journal of Economics, Management, And Business, 3(2), 98-110. https://doi.org/10.31311/jeco.v3i2.5635

Widodo, C. (2019). The Influence of Good Corporate Governance on Company Value with Moderation of Corporate Social Responsibility. Parameter Journal, 4(1).

Wulanningsih, S., \& Agustin, H. (2020). The Effect of Investment Opportunity Set, Company Growth, and Profitability on Firm Value. Exploratory Journal of Accounting, 2(3), 1-21.

Yuningsih, NN, \& Novitasari, NLG (2020). Effect of Managerial Ownership, Institutional Ownership, Dividend Policy and Investment Opportunity Set on Company Value of Manufacturing Companies 
Listed on the Indonesia Stock Exchange (IDX) 2016-2018. Journal of Applied Management and Accounting Science, 01(2), 76-91.

Zhang, Y., Chong, G., \& Jia, R. (2020). Fair value, corporate governance, social responsibility disclosure and banks' performance. Review of Accounting and Finance, 19(1), 30-47. https://doi.org/10.1108/RAF-01-2018-0016 